\title{
The Effects of Inspiratory Muscle Training in Neuromuscular Disorders: Review Article
}

\section{Okta Hariza $^{1}$, Budiati Lasmitasari ${ }^{1}$, Siti Chandra Widjanantie ${ }^{2}$, Nury Nusdwinuringtyas ${ }^{1}$}

${ }^{1}$ Department of Physical Medicine and Rehabilitation, Dr. Cipto Mangunkusumo Hospital, Faculty of Medicine, University of Indonesia, Jakarta

2 Department of Physical Medicine and Rehabilitation, Persahabatan Nastional Respiratory Hospital, Faculty of Medicine, University of Indonesia, Jakarta

\begin{abstract}
Introduction: Progressive inspiratory muscles weakness in neuromuscular disorders (NMD) can lead to respiratory impairments, from restrictive lung to respiratory failure. Inspiratory muscle training (IMT) is an exercise with a device to increase inspiratory muscles strength and/or endurance. This article was aimed to review the effect and prescription of IMT in NMD subjects.

Methods: Searching method was done in PubMed and Google Scholar using keywords: "inspiratory muscle training" AND "neuromuscular disorders" AND "MIP" OR "PImax".

Results: Seven related studies were found. These studies shown that IMT increased inspiratory muscles strength and/or endurance in chronic progressive NMD. Most studies used threshold type. The intensities varied from $30 \%$ through $70 \%$ of maximum inspiratory pressure (MIP), minimum twice a day. The repetition for strengthening was 10 times with 20 -seconds rest between repetitions. Endurance trainings were done in 10 cycles of 1-minute breathing or for total 20 minutes.

Conclusion: Several evidences reported that IMT significantly improve strength and endurance of inspiratory muscles in chronic progressive NMD. It was effective in earlier phase of NMD. The minimum load intensity was $30 \%$ MIP.
\end{abstract}

Keywords: Inspiratory muscle training (IMT), neuromuscular disorders (NMD), maximum inspiratory pressure (MIP) 


\section{ABSTRACT}

Pendahuluan: Kelemahan kekuatan otot inspirasi progresif pada penyakit neuromuskular (NMD) dapat mengakibatkan gangguan respirasi, dari penyakit paru restriktif hingga gagal nafas. Latihan otot inspirasi (IMT) adalah latihan dengan alat untuk meningkatkan kekuatan otot inspirasi dan/atau endurens. Artikel ini bertujuan untuk mereview efek IMT pada subjek NMD.

Metode: Metode pencarian dilakukan pada PubMed dan Google Scholar menggunakan kata kunci : "Latihan otot inspirasi” DAN “penyakit neuromuskular" DAN “MIP” ATAU "PImax".

Hasil: Tujuh penelitiaan terkait ditemukan. Penelitian ini menunjukkan bahwa peningkatan kekuatan otot inspirasi IMT dan/atau endurance pada NMD kronik progresif. Banyak penelitian menggunakan tipe ambang batas. Intensitas bervariasi dari 30\% hingga 70\% pada tekanan inspirasi maximum (MIP), minimal dua kali sehari. Pengulangan untuk penguatan dilakukan 10 kali dengan istirahat 20-detik diantara pengulangan. Latihan endurasi dilakukan dalam 10 siklus pada nafas 1-menit atau untuk total 20 menit.

Kesimpulan: Beberapa bukti melaporkan bahwa IMT secara signifikan memperbaiki kekuatan dan endurens otot inspirasi pada NMD kronik progresif. Efektif jika dilakukan pada fase awal NMD, dengan intensitas beban minimum $30 \%$ MIP.

Kata kunci: Latihan otot inspirasi (IMT), kelainan neuromuscular (NMD), tekanan inspirasi maksimal (MIP).

\section{Correspondent Detail:}

\section{Okta Hariza}

Email: oktahariza@gmail.com

Department of Physical Medicine and

Rehabilitation,

Dr. Cipto Mangunkusumo Hospital, Faculty of Medicine, University of Indonesia Jakarta, Indonesia

\section{INTRODUCTION}

Neuromuscular disorders (NMD) is defined as a group of disorders that involves pathology on the muscles, neuromuscular junctions, peripheral nerves and lower motor neurons, that lead to respiratory muscle weakness such as in muscular dystrophies, myasthenia gravis, inflammatory myopathies, etc. ${ }^{1,2,3}$

Respiratory muscles are needed to create a difference in pressure to inflate and deflate the lung, to achieve ventilation. ${ }^{4}$ Respiratory muscles are consisted of diaphragm, external intercostal muscle, and accessory breathing muscle. The weakened of respiratory muscle is also burdened with increasing elastic and resistive load as a result of worse lung and chest compliance, that also increasing airway resistance..$^{5-9}$ Progressive weakening of the inspiratory muscles, primarily the diaphragm and intercostal muscles causing chronic breathing problems in NMD. ${ }^{1,7}$ Inspiratory 
muscle weakness can be progressively causing restrictive lung disorders. It can cause the increased elastic load by decreasing lung and thoracic compliance, hypoventilation, ineffective cough and respiratory tract secretion. These changes will increase work of breathing, decrease efficiency of gas exchange, decrease tidal volume, and lead to perfusion-ventilation mismatch. ${ }^{10-16}$ On the chronic phase, restrictive lung disorders can lead to hypoventilation and hypercapnia. ${ }^{13,16}$ When there is weakness of expiratory muscle that is exacerbated by glottis dysfunction or inspiratory muscle weakness, the ability of airway secretions clearance will be impaired, increase risk of atelectasis and pneumonia. ${ }^{15}$

Inspiratory muscle strength can be evaluated by maximum inspiratory pressure (PImax or MIP) that is measured by mouth (most common) or by sniff nasal inspiratory pressure (SNIP). MIP is a noninvasive procedure. Individual will do maximal inspiration after expiration until the residual volume with open glottis through the occluded mouthpiece. ${ }^{7,18-19}$ Ventilation endurance test is measured as maximum sustainable ventilation (MSV), stated as a fraction of maximal voluntary ventilation (MVV), that measured by spirometer during a period of time in liter/minute. ${ }^{18}$

Inspiratory muscle training (IMT) is an exercise/intervention in order to increase inspiratory muscles strength and/or endurance or delay respiratory regression by utilizing external device with flow/resistive/threshold load in patient with or without ventilatory assistance. ${ }^{1,20-21}$

There is no consensus regarding to recommendations of exercise procedure in NMD, including inspiratory muscle training. Few conference about exercise in NMD have made suggestions, but have not been adopted by the clinician. ${ }^{22}$ This literature review was aimed to provide overview of the effects of IMT to the patients with NMD.

\section{METHODS}

Searching method of the literature was done in electronic databases PubMed and Google Scholar. We used keywords that consist of: "inspiratory muscle training" AND "neuromuscular disorders" AND "MIP" OR "PImax". Selection criteria for the articles are: published after the year 2000, interventional studies with or without control group, studies were done on chronic progressive NMD, studies assessed MIP or spirometry as outcomes. The exclusion criteria are: literature reviews, systematic reviews, articles that were not written in English, studies on disorders affecting central nervous system, and studies with expiratory muscle training. All the selected articles were analyzed and discussed by the authors.

\section{NEUROMUSCULAR DISORDERS}

\section{Definition}

Neuromuscular disorders (NMD) is defined as a group of disorders that involves pathology on the muscles, neuromuscular junctions, peripheral nerves and lower motor neurons. ${ }^{1,2}$ NMD that lead to respiratory muscle weakness include groups of muscular dystrophies (Duchene, Becker, limb- 
girdle, and facioscapulohumeral muscular dystrophy), myasthenia gravis, inflammatory myopathies, myopathies associated with trauma or medications, metabolic or congenital myopathies, neuropathies (hereditary and acquired), spinal muscular atrophy (SMA), poliomyelitis, myelopathies, and amyotrophic lateral sclerosis (ALS). ${ }^{3}$

\section{Role of Inspiratory Muscles in Ventilation}

Ventilation is a cycle, consisting of inspiratory and expiratory phases. To achieve ventilation, the respiratory muscles need to create a difference in pressure or a pressure gradient to inflate and deflate the lung. Pulmonary ventilation depends on balance between pressure produced by the respiratory muscles and the mechanical characteristic of the respiratory components opposing the respiratory muscle contractions. The force that the respiratory muscles have to overcome in the ventilation process can be represented by formula below: ${ }^{4}$

\section{$\Delta$ Force $=$ (Elasticity $x \Delta$ Volume) + (Resistance $x \Delta$ Flow)}

In the formula, the term (elasticity $\mathrm{x}$ volume) and (resistance $\mathrm{x}$ airflow) represent the elastic and resistive load of which the respiratory muscles or ventilator have to resist so that air can move into the lung, whereas the expiratory phase happens due to the lung elasticity. ${ }^{4}$

The primary inspiratory muscleis the diaphragm, a dome-shaped sheath of muscle that borders between the thoracic cavity and the abdominal cavity. ${ }^{1,4,5}$ The other main inspiratory muscle is external intercostal muscles. Expiration is a passive process by relaxation of the inspiratory muscles. Accessory breathing muscles contract during heavier inspiratory effort. ${ }^{4,6}$

\section{Pathophysiology of Respiratory System in Neuromuscular Disorders}

The cause of respiratory impairment can be varied in different NMD. ${ }^{7} \mathrm{NMD}$ can generally cause muscle weakness, including the muscles needed for respiration and bulbar muscle. ${ }^{8}$ The weakened muscle is also burdened with increasing elastic and resistive load as a result of worse lung and chest compliance, that also increasing airway resistance. ${ }^{9}$

Respiratory muscles are involved in majority of NMD in different stadiums and severity. ${ }^{9}$ In some cases it is involved in acute phase, for example in Guillain-Barre Syndrome (GBS), myasthenia gravis, and acute poliomyelitis. Nevertheless, most of respiratory muscles impairments are chronic and progressive. It may be involved in faster or slower progression. In ALS, respiratory impairment progresses rapidly, while in other NMD such as SMA, general myasthenia gravis, muscle dystrophies, and poliomyelitis, it progresses more slowly. ${ }^{9}$

Progressive weakening of the inspiratory muscles, primarily the diaphragm and intercostal muscles causing chronic breathing problems in NMD. ${ }^{1,7}$ Diaphragm paralysis can be caused by many factors including intrinsic diaphragm muscle weakness or phrenic nerve injury. ${ }^{11}$ Diaphragm paralysis can be seen in motor neuron diseases, myelopathies, neuropathies and myopathies. Diaphragm 
paralysis following phrenic nerve injury can result from thoracic surgery or mediastinal tumors. ${ }^{12}$ History of mechanical ventilation can also impair diaphragmatic movement and decrease it thickness. ${ }^{13,4}$

Respiratory muscle weakness can lead to some impairments and complications. Inspiratory muscle weakness can be progressively causing restrictive lung disorders. The other contribution factors are increased elastic load from decreasing lung and thoracic compliance, hypoventilation, ineffective cough and respiratory tract secretion. ${ }^{15,16}$ These changes will increase work of breathing, decrease efficiency of gas exchange, decrease tidal volume, and lead to perfusion-ventilation mismatch. ${ }^{14-16}$ On the chronic phase, restrictive lung disorders can lead to hypoventilation and hypercapnia. ${ }^{13,16}$

When expiratory muscle weakness is exacerbated by glottis dysfunction or inspiratory muscle weakness, the ability of airway secretions clearance is severely impaired. This will increase airway resistance and change breathing mechanics, then increase risk of atelectasis and pneumonia. Respiratory muscle weakness, spine and rib cage deformity, upper airway tract muscle weakness, obesity, craniofacial abnormalities, and poor ventilation control also have potential to increase the risk of sleep-disordered breathing. ${ }^{15}$

On the late onset of NMD, when the increased work of breathing exceeded the respiratory muscle endurance, respiratory muscle failure will happen. ${ }^{1,7,15}$ Imbalance between the load and capacity cause muscle fatigue and respiratory pump failure. ${ }^{5,7,15}$ Respiratory disorder is seen as the primary cause of death in NMD. At the end, it can cause chronic respiratory insufficiency, increased risk of infection, and respiratory failure, that can increase mortality. ${ }^{1,8,17}$

\section{Measurement of inspiratory muscle strength and endurance}

The simple and most common measurement to evaluate inspiratory muscle strength is maximum inspiratory pressure (PImax or MIP) that is measured by mouth. ${ }^{17,18}$ MIP is a noninvasive procedure, where an individual is doing maximal inspiration after expiration until the residual volume with open glottis through the occluded mouthpiece. ${ }^{7}$ Sniff nasal inspiratory pressure (SNIP) is the less common measurement of inspiratory muscle strength, by placing probe in one nose-hole then doing sniff maneuver. ${ }^{1}$ It is a complementary measurement to effectively rule out inspiratory muscle weakness in individuals with low MIP values. ${ }^{19}$

Inspiratory muscle endurance is defined as the ability to sustain a level of minute ventilation or inspiratory pressure. Ventilation endurance test is measured as maximum sustainable ventilation (MSV), typically stated as a fraction of maximal voluntary ventilation (MVV). MVV is maximum respiratory volume measured by spirometer during a period of time, described in liter/minute, typically 12 seconds for normal subjects (12s-MVV). ${ }^{19}$

\section{Inspiratory muscle training}

Inspiratory muscle training (IMT) is defined as exercise/intervention in order to increase inspiratory muscles strength and/or endurance or delay respiratory regression by utilizing 
external device with flow/resistive/threshold load in patient with or without ventilatory assistance. ${ }^{1}$ The exercises were done with the patient in sitting position and use a nose-clip. The patient was instructed to inhale as fast as possible with maximum effort while resisting the load on the IMT device. Two most common types of the device are resistive and threshold. Resistive IMT device works by decreasing the opening of airway flow channel, thus creating constant resistance throughout the entire breathing volume. Threshold IMT device typically contain a spring valves, which will be open after threshold pressure is reached, thus creating strong resistance only in the initial inspiratory volume. ${ }^{19,20}$

\section{Inspiratory Muscle Training Intervention on Chronic Progressive Neuromuscular Disorder}

There were seven studies that suitable with the selection criteria. All studies reported IMT intervention on chronic progressive NMD, on children or adult subjects. The subjects were patients with muscular dystrophy, ${ }^{21,22}$ ALS, ${ }^{22,23}$ generalized myasthenia gravis, ${ }^{11}$ and postpolio syndrome. ${ }^{26}$ Two studies included patient with muscular dystrophy and spinal muscular atrophy. ${ }^{21-23}$

Some studies compared the training group of subjects with the control group.Cheah and Pinto used placebo/sham training as intervention in the control groups. ${ }^{24}$ Yeldan and Fregonezi compared IMT with conventional breathing exercise. ${ }^{11,23}$

The results from the studies are varied, but most of the studies evaluated the effects of IMT to the inspiratory muscle strength and/or endurance. ${ }^{11,23}$ Yeldan carried out study on 23 patients with muscular dystrophies, divided into two groups. The IMT group received pressure loads that are gradually increased every week, according to the PImax result. The exercise was done twice a day for 15 minutes, with rest between 10 repetitions. The breathing exercise group was instructed to do diaphragmatic and segmental breathing exercises. After 12 weeks of training, the result showed that PImax in the IMT group increased significantly higher $(37.50 \pm 22.75)$ than the breathing exercises group $(19.00 \pm 16.70) .{ }^{23}$

Cheah studied intervention of threshold IMT for 12 weeks on subjects diagnosed with ALS/motor neuron disease. The IMT group was given IMT with an initial load of $15 \%$ maximum SNIP that was increased each week. Even though the result was not statistically significant, it was reported that the increase of MIP in the IMT group is higher than the sham group. ${ }^{24}$

Koessler reported an interventional study on 18 patients with Duchenne muscular dystrophy and 9 patients with SMA with vital capacity above $25 \%$. Subjects were divided into three groups based on their vital capacity. The subjects used resistive IMT for resistance training and maximum static inspiration maneuver for endurance training. The training was done at home with 10 cycles of loadedbreathe, each for 1 minute, with 20 seconds rest between cycles, twice a day. The load was adjusted every three months for $70-80 \%$ of PImax. Endurance training was done with 10 repetitions of static maximum inspiratory efforts until the minimum pressure was $90 \%$ of MIP, with 20 seconds rest between maneuvers. 
In all groups, PImax was increased significantly up to 10 months after the plateau phase, and was not declined until the training period was over. There was also significant increase in 12-s maximum voluntary ventilation test $(12 \mathrm{~s}-\mathrm{MVV})$ in all groups. ${ }^{27}$

Fregonezi did an RCT using 75 patients with stable generalized Myasthenia gravis. The exercise group was trained with threshold IMT, combined with diaphragmatic breathing and pursed-lip breathing exercise for 10 minutes, three times a week for 8 weeks. The threshold load was increased gradually from $20 \%$ to $60 \%$ of PImax for 8 weeks, starting from $20 \%$ of PImax on the first week, $30 \%$ on the third week, $45 \%$ on the fifth week and $60 \%$ on the seventh week. After 8 weeks, the result showed a significant difference improvement in training group compared to control group in PImax, respiratory rate/tidal volume ratio, and upper chest wall expansion. ${ }^{11}$

Pinto studied 26 patients with ALS with normal respiratory function divided into two groups. First group started active inspiratory exercise at entry and were followed for eight months. The second group followed placebo exercise for the first four months and then active exercise for the second four-month. Active exercise was breathing with threshold IMT twice daily, for 10 -minute period. In the active exercise period, the load was set to $30-40 \%$ of the MIP. The placebo-period exercise consisted of breathing through the respiratory device with the lowest possible load. Within-group analysis suggested that inspiratory exercise promotes a transient improvement in the maximal voluntary ventilation and sniff inspiratory pressure, with no significant difference between groups. ${ }^{24}$
Winkler reported IMT intervention in patients with Duchenne muscular dystrophy and spinal muscular atrophy. Both strength and endurance training were performed twice daily at home. Patients were instructed to do resistive breathing against variable inspiratory resistance for endurance training or maximal static inspiratory efforts against the almost occluded resistance for strength training. ${ }^{24}$

\section{DISCUSSION}

Several studies have shown that IMT can increase the strength and/or endurance of the inspiratory muscles in muscle dystrophies, ALS, SMA, generalized Myasthenia Gravis, and post-polio syndrome. Most of the studies used threshold type IMT device. The load intensities for training were varied from $30 \%$ through $70 \%$ of maximum inspiratory pressure (MIP). ${ }^{11,23,24}$ IMT needs a minimum load of $30 \%$ MIP to effectively increase inspiratory muscle strength. The number of repetition to strengthen the inspiratory muscles is 10 times with 20 -seconds rest between repetitions. ${ }^{23,24}$ Training for the inspiratory muscles endurance can be done in 10 breathing cycles of 1-minute duration or for total 20 minutes. ${ }^{24}$ The exercise should be done minimum for twice a day. ${ }^{23,24}$

Cheah also reported higher improvement of inspiratory muscle strength in the IMT group compared to the control in subjects with ALS. ${ }^{21}$ The load intensity in those studies were increased gradually after a period of training. ${ }^{11,23,24}$ The mechanism of increased respiratory muscle strength was associated with structural and neural adaptation. Similar with the skeletal muscles, respiratory muscles 
can also adapt to training through structural adaptation by hypertrophy. and neural adaptation by recruitment of additional motor unit and increasing the frequency of muscle fibers contraction..$^{21-24}$

Pinto reported a transient improvement in the respiratory muscle endurance after IMT training in ALS patient. ${ }^{22}$ After a continuous low-intensity training for a longer duration, like other muscles in general, the respiratory muscles undergo structural (an increase of oxidative fibers and capillary density) and biochemistry changes, resulting in better muscle endurance. ${ }^{21,22,24}$

Some studies showed that IMT was more appropriate for early phase of chronic progressive NMD. Winkler found that IMT useful in the early stages of NMD, with inspiratory vital capacity declined by less than $10 \%$ during the year before initiation of training. ${ }^{24}$ The training may be harmful in late phase of the diseases. The resistance training is not suggested for patients with high risk of respiratory complication such as increasing dyspnea after training or lung infection that can trigger inspiratory muscle fatigue. ${ }^{21-24}$

\section{CONCLUSION}

Several studies reported that inspiratory muscle training (IMT) in chronic progressive NMD, significantly improve strength and endurance of inspiratory muscles. The improvement of inspiratory muscle strength can be measured by maximum inspiratory pressure (MIP/PImax) or sniff nasal inspiratory pressure (SNIP), whereas the improvement of inspiratory muscle endurance can be measured by maximal voluntary ventilation (MVV). Inspiratory muscle training was effective in patients with earlier stages of diseases, with minimum load intensity of $30 \%$ MIP.

\section{REFERENCES}

1. Human A, Corten L, Jelsma J, Morrow B. Inspiratory muscle training for children and adolescents with neuromuscular diseases: A systematic review. Neuromuscular Disorders. 2017; 27: $503-17$.

2. McDonald CM. Clinical approach to the diagnostic evaluation of hereditary and acquired neuromuscular diseases. Phys Med Rehabil Clin N Am. 2012; 23(3): 495-563.

3. Pedrosa R, Silva IS, Azevedo IG, Forbes AM, Fregonezi GAF, Dourado Junior MET, et al. Respiratory muscle training in children and adults with neuromuscular disease (Protocol). Cochrane Library. 2015; 5: 1-12.

4. Kacmarek RM, Stoller JK, Heuer AJ. Egan's fundamentals of respiratory care. 11th edition. 2017.

5. Allen J. Pulmonary complications of neuromuscular disease: A respiratory mechanics perspective. Paediatric Respiratory Reviews. 2010; 11: 18-23.

6. Kharma N. Dysfunction of the diaphragm: imaging as a diagnostic tool. Curr Opin Pulm Med. 2013;19:394-8.

7. Schoser B, Fong E, Geberhiwot T, 
Hughes D, Kissel JT, Madathil SC, et al. Maximum inspiratory pressure as a clinically meaningful trial endpoint for neuromuscular diseases: a comprehensive review of the literature. Orphanet Journal of Rare Diseases. 2017; 52: 1-12.

8. Tanšek MJ. Specific inspiratory muscle training can improve the overall functionality of the inspiratory muscles and contibutes to reduction of respiratory complications. Physiotherapia Croatica. 2016; 14: 64-7.

9. Lo Mauro A, Aliverti A. Physiology of respiratory disturbances in muscular dystrophies. Breathe. 2016; 12: 318-27.

10. Fauroux B, Khirani S. Neuromuscular disease and respiratory physiology in children: putting lung function into perspective. Respirology. 2014; 19: 782 91.

11. Kokatnur L, Rudrappa M. Diaphragmatic Palsy. Disease.s 2018; 6(16): 1-14.

12. Pasparaki E, Bibaki E, Meletis $\mathrm{Y}$, Ferdoutsis E. Neuromuscular diseases and respiratory system. Pneumon. 2017; 30(3): 176-87.

13. Fayssoil A, Behin A, Ogna A, Mompoint D, Amthor H, Clair B, et al. Diaphragm: pathophysiology and ultrasound imaging in neuromuscular disorders. Journal of Neuromuscular Diseases. 2018; 5: 1-10.

14. Ambrosino N, Carpene N, Gherardi M. Chronic respiratory care for neuromuscular diseases in adults. Eur Respir J. 2009; 34: 444-51.

15. Aboussouan LS. Mechanisms of exercise limitation and pulmonary rehabilitation for patients with neuromuscular disease. Chronic Respiratory Disease. 2009; 6(4): 231-49.

16. Benditt JO, Boitano LJ. Pulmonary issues in patients with chronic neuromuscular disease. Am J Respir Crit Care Med. 2013; 187(10): 1046-55.

17. Kaminska M, Noel F, Petrof BJ. Optimal method for assessment of respiratory muscle strength in neuromuscular disorders using sniff nasal inspiratory pressure (SNIP). PLoS ONE. 2017; 12(5): e0177723. Available at: https:// doi.org/10.1371/journal.pone.0177723

18. Bausek N, Berlin T, Aldarondo S. The power and potential of respiratory muscle training. Respiratory Equipment and Devices Exhibition Mgazine. 2016; p.8696.

19. Wu W, Zhang X, Lin L, Ou Y, Li X, Guan $\mathrm{L}$, et al. Transdiaphragmatic pressure and neural respiratory drive measured during inspiratory muscle training in stable patients with chronic obstructive pulmonary disease. International Journal of COPD. 2017; 12: 773-81.

20. Anziska Y, Sternberg A. Exercise in neuromuscular disease. Muscle Nerve. 2013; 48: 3-20.

21. Cheah BC, Boland RA, Brodaty NE, et al. INSPIRATIonAL - INSPIRAtory muscle training in amyotrophic lateral sclerosis. Amyotroph Lateral Scler. 2009; 10: 384-92.

22. Pinto S, de Carvalho M. Can inspiratory muscle training increase survival in earlyaffected amyotrophic lateral sclerosis 
patients? Amyotrophic Lateral Sclerosis and Frontotemporal Degeneration. 2013; 14(2): 124-6.

23. Huang $\mathrm{CH}$, Yang $\mathrm{GG}, \mathrm{Wu} \mathrm{YT}$, Lee $\mathrm{CW}$. Comparison of inspiratory muscle strength training effects between older subjects with and without chronic obstructive pulmonary disease. Journal of the Formosan Medical Association. 2011; 110(8): 518-26.

24. Pinto S, de Carvalho M. Breathing new life into treatment advances for respiratory failure in amyotrophic lateral sclerosis patients. Neurodegenerative Disease Management. 2014; 4(1): 83-102. 